\title{
KENYÉR ÉS PÉKSÜTEMÉNY FOGYASZTÁSI SZOKÁSOK A GLUTÉNMENTES DIÉTÁBAN
}

\author{
- nी \\ BREAD AND BAKED GOODS CONSUMPTION HABITS IN THE GLUTEN FREE DIET \\ - ia. \\ ${ }^{1}$ CSAPÓNÉ RISKó, Tünde \\ 2PÉNTEK, Ádám \\ ia. \\ ${ }^{1}$ Debreceni Egyetem, Gazdaságtudományi Kar, Marketing és Kereskedelem Intézet \\ (University of Debrecen, Faculty of Economics and Business, Institute of Marketing and Commerce) \\ H-4032 Debrecen, Böszörményi út 138. \\ e-mail: risko.tunde@econ.unideb.hu \\ ${ }^{2}$ Debreceni Egyetem, Gazdaságtudományi Kar, Alkalmazott Informatika és Logisztika Intézet \\ (University of Debrecen, Faculty of Economics and Business, Institute of Applied Informatics and Logistics) \\ H-4032 Debrecen, Böszörményi út 138 .
}

\begin{abstract}
gl Celiac disease is a genetic autoimmune disorder which is the result of an immune system response to the ingestion of gluten in susceptible persons. Gluten is a generalised term that describes the storage proteins found in the common cereal grains: wheat, rye, barley and their derivatives. This disease is permanent and damage to the small intestine always occurs when gluten is consumed, regardless of whether symptoms are present or not. Celiac disease affects about 1 in 100 individuals worldwide. In Hungary 1-2 percent of the population is affected. The only treatment for people with celiac disease is lifelong adherence to a gluten-free diet. On a gluten-free diet, wheat, rye, barley and any foods or ingredients derived from them must be removed from the diet. Bread is basic and frequently consumed food made from wheat. Bread and salty and sweet baked goods are an essential part of the Hungarian eating habits. The market of gluten-free foods is continuously increasing worldwide. Among the reasons behind this trend the increasing number of diagnosed persons, their family members (with whom they eat together), healthy lifestyle and fashion lifestyle have to be pointed out. Several gluten-free bread and baked goods brands are available on the Hungarian market. The ingredients, texture, colour, softness of the available breads and baked goods are rather different. There is a big choice of gluten-free flour mixtures on the Hungarian market, as well. The compositions of these mixtures are also rather different. The aim of our empirical research was to investigate the gluten free bread and baked goods consumption habits of people following gluten-free diet.
\end{abstract}

KuLCSSZAVAK: glutén, cöliákia, kenyér, diéta, fogyasztói szokások

JEL-KóDok (JEL CODES): I12, M31

DOI: https://doi.org/10.20494/TM/5/1/6
KEYwORDS: gluten, coeliakia, bread, diet, consumption 


\section{BEVEZETÉS - INTRODUCTION}

A cöliákia (lisztérzékenység) nem allergia, hanem autoimmun betegség, amely örökletes, környezeti (glutén) és immunológiai komponensekből tevődik össze. Olyan immunválaszként jellemezhető, amikor az elfogyasztott gabonák (búza, rozs, árpa, zab) fehérjéinek hatására a vékonybélben gyulladás, a bélbolyhok atrófiája és a kripták hiperláziája következik be. A cöliákia az európai lakosság 1-3 százalékát érinti, azaz legalább 5 millió embert. A betegek 80 százaléka éli életét a helyes diagnózis nélkül. A fel nem ismert betegség következményei súlyos szövődmények és társult betegségek lehetnek. A már diagnosztizált betegek terápiája a dieto-terápia, azaz az élethosszig tartó, szigorú gluténmentes diéta. A cöliákiát a szakképzett orvos ma már pontosan be tudja azonosítani, így csak azoknak szükséges gluténmentesen táplálkozni, akik biztosan lisztérzékenyek. A lisztérzékenység aktívan kutatott terület az orvostudományon belül és a mai ismeretek alapján kijelenthető, hogy a lisztérzékenyek számára egészségük megőrzése érdekében a gluténmentes diéta betartása kötelező (KLICSU és PÁLFI, 2007; UTASSY, 2012; WEBORVOS, 2016).

A gluténmentes diéta azt jelenti, hogy glutént, vagy ahhoz hasonló szerkezetű fehérjéket tartalmazó búzát, rozst, árpát, zabot és ezek keresztezett változatait tartalmazó élelmiszereket, továbbá gluténnal szennyezett élelmiszereket tilos fogyasztani. Vannak glutént biztosan tartalmazó élelmiszerek (pl. hagyományos kenyerek, péksütemények, tésztafélék, cukrászsütemények), glutént potenciálisan tartalmazók (pl. félkész ételek, öntetek, leves porok, füszerkeverékek, tészta szószok) és glutént eredendően nem tartalmazók (pl. friss zöldségek, gyümölcsök, tojás, nyers húsok). A gluténmentes diéta nem jelenti azt, hogy az első két csoportba sorolt élelmiszereket teljes mértékben nélkülözni kellene. Le kell őket cserélni garantáltan gluténmentesre. Ma már találhatunk alternatívákat (kenyérre, péksüteményekre, száraztésztákra, kekszekre, öntetekre, füszerkeverékekre stb.) a nagyobb kereskedelmi láncok és szakboltok polcain (KOLTAI, 2016a).

A 2016. évi „Free from food expo” forradalminak tekinthető, hiszen mind a kiállítók, mind a látogatók száma rekordot döntött. Több mint 250 kiállító jelent meg legújabb termékeivel. Ez is igazolja, hogy a mentes piac továbbra is dinamikusan növekszik, nemcsak Európában, hanem világszerte. A gyártó cégek és a piac növekedését az innováció tartja mozgásban, aminek egyik hozománya, hogy napjainkra a gluténmentes diétára divatként is kell tekintenünk, mivel sokan követik akkor is, hogyha nem szenvednek ebben a betegségben. Emiatt a gluténmentes élelmiszerek értékesítési trendje folyamatos növekedést mutat (KOLTAI, 2016b). A gluténmentes termékek piacán mintegy húsz éve indult be jelentős fejlődés, egyre több és több gyártó jelent és jelenik meg, egyre több és több termék válik elérhetővé a gluténmentes diétát követők számára. Hozzá kell azonban tenni, hogy ez a bővülés csak részben vezethető vissza a lisztérzékenyek számának növekedéséhez. A napjainkban uralkodó divat diéták között fellelhetô a gluténmentes étrend is (AMIN et al., 2002). A gluténmentes divat nyugatról indult, Amerikában már 2014-ben a háztartások 11 százaléka vásárolt gluténmentes élelmiszereket, miközben a lakosságnak csak mindössze 1 százaléka lisztérzékeny. Gluténmentes élelmiszerek mellett az Egyesült Államokban gluténmentes kutyatáp is létezik (AXELSSON et al., 2013). A gluténmentes divathullám elérte hazánkat is. A legnagyobb hazai élelmiszer láncok és gyártók megerősítették, hogy meredeken emelkedik a kereslet a mentes termékekre. A Tesco-tól és Spar-tól kapott információk alapján náluk 2530 százalékkal nőtt a gluténmentes termékek eladása (HANULA, 2016). Becslések szerint a gluténmentes termékek piaca Európában a 2012. évi o,9 milliárd euróról 2017-re eléri az évi 1,3 milliárd eurót. A vásárlók között nem csak lisztérzékenyeket és már említett divat diétázókat találunk, hanem olyanokat is, akik egyéb egészségügyi problémájuk miatt követik ezt a diétát (WHITEMAN, 2018). A gluténmentes piac bővüléséhez mindezeken túl hozzájárul még, az egészséges életmód népszerüsége, valamint az a gyakorlat, hogy a lisztérzékenyeknél gyakran a család többi egészséges tagja is követi a gluténmentes diétát (KOLTAI, 2017).

Azonban, az indokolatlan gluténmentes diétának vannak negatív hatásai. A gluténmentes gabonák kevesebb B-vitamint, folsavat, 
kalciumot, vasat és élelmi rostot tartalmaznak (THOMPSON, 2000). A gluténmentes ételekben is kevesebb a B-vitamin, a kalcium, a vas, a cink, a magnézium, és a rostok. A lisztérzékenyek jó esetben ennek tudatában vannak, és más forrásokból pótolják ezeket, a divat diétázók azonban nem biztos (WHITEMAN, 2018). A hiányok mellett azt is meg kell említenünk, hogy a gluténmentes élelmiszereknek magasabb a hozzáadott cukor- és zsírtartalmuk is (WHITEMAN, 2018). AMIN (2015) is utal rá, hogy a gluténmentes ételekben több adalékanyag, cukor és zsír lehet, vagyis akik egészségtudatosságból tértek át a gluténmentes diétára, nem lesznek egészségesebbek, sőt ezen élelmiszerek hozzá is járulhatnak a hízáshoz. „A gluténmentes étkezés diéta, de nem fogyókúra, a gluténnek sem az egészségtudatos életmódhoz, sem a hízáshoz sincs semmi köze. A lisztérzékenység egyszerüen kényszer" írja LUKÁCS (2018). Jellemző példa, hogy a Barilla gluténmentes tésztájában több a szénhidrát viszont kevesebb a fehérje, mint a teljes kiőrlésű változatban. A Betty Crocker gluténmentes Bisquick lisztjében viszont több a cukor, így jobban hizlal, mint a hagyományos (JARGON, 2014). A Glutino márkájú almás, fahéjas müzliben egyáltalán nincs A és C-vitamin, míg a Cheerios sima, gluténes verziójában a napi szükséges A- és C-vitaminbevételéből 10 százalékot fedez a termék, de folsav, vas és kalcium is van benne (10\% kalcium és $25 \%$ folsav). A Glutino egyáltalán nem tartalmazza az ásványi anyagokat. A már említett Bisquicknél hasonló a helyzet, a hagyományos verzióban van B-vitamin ( $\mathrm{B}_{1}$, B2, B3, B6, B9), folsav, vas, a gluténmentesben viszont egyik sincs (LUKÁCS, 2018).

Amilyen egyszerűnek tűnik azonban az orvos által előírt szigorú gluténmentes diéta, a gyakorlat során kiderül, hogy nem is annyira egyszerü követni azt. Hogyan kerülhet glutén a diétába?

- Az alapanyag valójában nem gluténmentes. Ez elkerülhető a gluténmentes védjeggyel, gluténmentes termékmegjelöléssel ellátott élelmiszerek vásárlásával. Javasolt a speciális üzletekben, szakboltokban való vásárlás, ahol lehetőség nyílik részletesebben érdeklődni az alapanyagok eredetéről.

- A gluténmentes élelmiszer készítése so- rán gyártási szennyeződés következik be. A gluténmentes diétához nem elégséges csupán az alapanyagok gluténmentessége, hiszen az ilyen élelmiszerek gyártása során gyártási szennyeződés is felléphet, ha az üzem, vagy konyha másféle termékeket, ételeket is készít.

- A gluténmentes ételek szállítása és tárolása során kontakt ételszennyeződés történhet. Csak a teljes felületén zárt, sértetlen csomagolásban szállított ételek, élelmiszerek nem érintkeznek más élelmiszerekkel, így elkerülhető a kontakt ételszennyeződés. A megfelelő csomagolás mellett meg kell említeni az emberi figyelmetlenségből adódó összecserélés veszélyét is, amennyiben egy szállítójármüben kerülnek különböző élelmiszerek szállításra. Csak olyan élelmiszert szabad megvásárolni, átvenni, amelynek a csomagolása nem sérült.

- A diéta be nem tartása. Gyakran adódik lehetőség elcsábulásra, nem mindig könnyü betartani a diétát. Amikor ilyen helyzetbe kerül a diétázó, arra kell gondolnia, hogy mennyi panasztól, kellemetlenségtól óvja meg magát és menynyi betegséget kerülhet el, ha tudatosan tartja a gluténmentes diétát (UTASSY, 2012).

A GfK Hungária 2010-re vonatkozó kutatásából kiderült, hogy az elmúlt 20 évben a hazai pékárupiacon legnagyobb mennyiségi részesedést felmutató fehér kenyér fogyasztása fokozatosan csökkent, de még mindig a leggyakrabban fogyasztott öt élelmiszer között van. Kiflit és zsömlét is gyakran fogyasztanak, mindkét termékcsoport a tíz leggyakrabban fogyasztott élelmiszer között található. A 15 évnél idősebb lakosság háromnegyede hetente többször fogyaszt fehér kenyeret, 58 százalékuk csaknem napi rendszerességgel. Kiflit, zsömlét három felnőttből kettő fogyaszt hetente több alkalommal. A magyar háztartások vásárlási adatai alapján az egy főre eső fogyasztás kenyérből 50 kilogramm, kifliből 60 darab, zsömléből pedig 150 darab volt 2010-ben. Kenyeret a háztartások egy év alatt 67 alkalommal vettek, vagyis megközelítőleg ötnaponta. Friss kenyérre, kiflire, zsömlére és egyéb friss pékárura 196 
milliárd forintot költöttek a magyar háztartások 2010-ben (GFK, 2011).

Glutén nélkül sütni-fözni, egy süteményt úgy elkészíteni, hogy az ne essen szét, olyan kenyeret, péksüteményt sütni, ami hasonló élvezeti értékkel bír, mint a hagyományos, gluténtartalmú kenyerek, péksütemények, sütemények nagy kihívás. A glutén teszi a tésztát kompakttá. A gluténmentes sütés-fözés nemcsak technológiai szempontból különbözik a hagyományostól, lelkiismeretes munkát igényel az innovatív hozzávalók kutatása és az új receptek kifejlesztése (YOURLIFE, 2010). A sikérmentesség biztosítása a gluténmentes diétában alapvető fontosságú. Olyan állagú és formájú tészta készítése a cél, amely a búzalisztből készülthez a legközelebb áll. Számos sikérhelyettesítő áll rendelkezésre, mint például a xantán, guármagliszt, agar-agar, útifümaghéj, lupin rost, almarost vagy a chia mag. A sikérmentesség biztosítása mellett meg kell említeni a rendelkezésre álló alternatív gabonaféleségeket és álgabonákat is, melyekkel kiválthatóak a gluténtartalmú gabonák. Ilyen alternatív lehetőség a köles, a teff, a cirok, a quinoia, az amaránt, a hajdina, a rizs, burgonya vagy a kukorica. A jelenleg elérhető gluténmentes sütőipari termékeket alacsonyabb élvezeti érték és tápérték jellemzi a hagyományos termékekhez képest. A gluténmentes gabonák kevesebb B-vitamint, folsavat, kalciumot, vasat és élelmi rostot tartalmaznak. A hasznos prebiotikumok és probiotikumok alkalmazásával a gyártók költséghatékonyan és biztonságosan tudják növelni gluténmentes termékeik technológiai és táplálkozási minőségét is. A feldolgozott gluténmentes termékekben kevesebb a B-vitamin, a kalcium, a vas, a cink, a magnézium és rostok. Éppen ezért igen fontos, hogy a gluténmentes diétát követők minél nagyobb arányban fogyasszák az olyan gluténmentes gabonaféléket, dióféléket, magvakat, amelyeknek magas a rost-, vas-, cink- és más fontos tápanyag-tartalma. A hajdina és a köles rendkívül előnyösek lehetnek a gluténmentes diéta során kialakuló hiányok pótlására (THOMPSON, 2000; HANULA, 2016). Azoknak akik gluténmentes diétában kenyeret és péksüteményeket szeretnének fogyasztani, két lehetőségük van: vásárolják őket vagy sütik maguknak. Számos gluténmentes kenyér és péksütemény gyártó és márka jelen van a magyar piacon, bár az öszszetétele, textúrája, színe, rugalmassága ezen termékeknek igen eltérő, különösképpen a hagyományos kenyerekkel, péksüteményekkel összevetve őket. Kutatási eredmények is alátámasztják, hogy a boltok polcain sajnos sok gluténmentes kenyér gyenge minőségü és ízű, szárazak, morzsálódó az állaguk, ami nem szimpatikus a friss, lágy, magasabb nedvességtartalmú kenyérféléket kereső fogyasztóknak (YLIMAKI et al., 1991; ARENDT et al., 2002; GALLAGHER, GORMLEY és ARENDT, 2003). Ha valaki sütni szeretne kenyeret, péksüteményt gluténmentes lisztekből és liszt keverékekből is meglehetősen nagy és egyre bővülő a választék a hazai piacon. Ezen lisztkeverékek összetétele is igen különböző, ezért is gyakori az, hogy a gyártó saját lisztkeverékéhez recepteket is ajánl. A sikeres gluténmentes kenyérsütésnek több feltétele is van. Legyen elérhető folyamatosan a jó minőségü alapanyag, jó, bevált recept és idő az elkészítéshez. Mindemellett ha elérhető áron, beszerezhető a jó minőségü gluténmentes kenyér, az is befolyásolhatja a sütési hajlandóságot. Amint láthatjuk, ez egy többtényezős kérdés. Megfigyeléseink szerint az előbb felsorolt tényezők másként érhetőek el az egyes település típusokban, viszont Magyarország tradicionálisan nagy kenyérfogyasztó ország. Ez azt jelenti, hogy a lakosság túlnyomó része folyamatosan és naponta többször fogyaszt kenyeret, péksüteményeket. Kutatási kérdéseink közül az első, hogy a gluténra érzékenyek mit és hogyan fogyasztanak a mindennapok során? Milyen módon jutnak hozzá a mindennapi fogyasztásaik során a pékárúhoz. Ezek különösen lényeges kérdések a piac öszszes szereplője esetében.

\section{ANYAG ÉS MÓDSZER - MATERIALS AND METHODS}

A kenyerek és péksütemények alapvető és gyakran fogyasztott élelmiszerek, amelyek hagyományosan búzalisztből, illetve gabonaliszt keverékekből készülnek. A gluténmentes diétát folytatók is fogyasztanak kenyeret, péksüteményeket, de természetesen gluténmentes változatban. Primer kutatásunk célja az volt, hogy megvizsgáljuk a kenyér- és péksütemény vá- 
sárlási és -fogyasztási szokásokat gluténmentes diétát folyatatók körében. Miután elég nagy választék áll rendelkezésre mind gluténmentes kenyerekből, péksüteményekből, valamint gluténmentes lisztekből, lisztkeverékekből, kíváncsiak voltunk arra, hogy a válaszadók milyen gyakran és mely fó étkezésekhez fogyasztanak kenyeret, vásárolják vagy inkább sütik a kenyeret maguknak. Mindkét esetben (vásárlás - sütés) vizsgáltuk a motivációkat, gyakoriságokat és a preferált márkákat. A gluténmentes péksüteményekhez kapcsolódó fogyasztói szokások vizsgálata kitért a péksüteményekhez kötődő vásárlási gyakoriságra, vásárlási helyszínekre, elégedettség vizsgálatra mind a hazánkban elérhető péksütemények választékára, azok minőségére és árára vonatkozóan.

Internet alapú kérdőíves megkérdezést végeztünk 2017 januárjában 2 héten keresztül a magyar fogyasztók körében. Az online kitölthető kérdőívet négy zárt gluténmentes Facebook közösségben osztottuk meg. Ezek a közösségek igen aktívak és nyitottak a gluténmentes életmód, illetve táplálkozás terén az egymással való információ megosztásban. A minta nagysága: 196 fő. Bár Magyarországon az érintettek száma körülbelül 90 ooo fó, de a diagnosztizáltak száma sajnos csak ennek a 10\%-a (KOLTAI, 2012). Így véleményünk szerint az elért elemszám értékelhetően bemutatja e csoport attitűdjeit a kutatással kapcsolatban. A kérdőívben szerepeltettünk zárt, feleletválasztós, skálás és demográfiai kérdéseket. A csoport tagjairól elmondható, hogy nem divat miatt tartják a gluténmentes étrendet, hanem mert lisztérzékenyek.

Válaszadóink 89,7 százaléka nő és 10,3 százaléka férfi. Egy magyarországi kutatás feltárta, hogy a cöliákia sokkal több nőt (81 százalék) sújt, mint férfit (19 százalék) (VOJNITS, 2012), azaz a nők nagyobb száma a mintában nagy valószínűséggel erre vezethető vissza. A kérdőívet kitöltők között találunk olyat, aki már több mint 20 éve, de van, aki csak pár hónapja él gluténmentes étrenden. A válaszadók 24,4 százaléka a fővárosban él, 20,5 százaléka megyei jogú városban, 25,6 százaléka egyéb városokban és 29,5 százaléka egyéb településtípuson. Válaszadóink képviselték Magyarország mind a hét NUTS 2 régióját. Válaszadóink iskolai végzettségét tekintve, a válaszadók fele felsőfokú végzettséggel, 38,5 százaléka érettségivel és közel
6-6 százaléka 8 általánossal vagy szakmunkásképzővel rendelkezik. A válaszadók aktvitását tekintve 41 százaléka aktív szellemi, 21,8 százaléka aktív fizikai dolgozó, míg 20,5 százaléka tanuló. Találunk még igen kis arányban GYES/ GYED-en lévőt, munkanélkülit és nyugdíjast is. Családi állapotukat tekintve a válaszadók 62,8 százaléka élettárssal élő, illetve házas, 29,5 százaléka hajadon/nőtlen és 7,7 százaléka elvált. Anyagi helyzetüket tekintve 17,9 százalékuk jelentősen átlag feletti, 11,5 százalékuk átlag feletti, 44,9 százalékuk átlagos, 15,4 százalékuk átlag alatti jövedelműnek, vallja magát. A fennmaradó válaszadók között egyenlő arányban vannak a jelentősen átlag alatti és a saját jövedelemmel nem rendelkezők.

Az eredményeket ismertető fejezet első részében a leíró statisztika segítségével kívánunk átfogó képet felrajzolni a gluténmentes kenyér és péksütemény fogyasztási szokásokról. A bevezetésben megfogalmazott kérdés megválaszolására az eredményeket bemutató fejezet második részében vizsgáljuk a felállított hipotézist, melynek a megerősítéséhez kereszttáblás elemzést használtunk. A kereszttáblákat két nem paraméteres nominális vagy ordinális változó összefüggésének vizsgálatára alkalmazhatjuk. A táblázat munkaterületének cellái, tartalmazzák a két változó értékeinek minden kombinációja esetén kapott értékeket. Melyek a cím oszlopban és a cím sorban lévő változók közötti összefüggésekről nyújtanak információt. A Pearson-Chi ${ }^{2}$ próbát gyakran használják a nominális változók statisztikáiban hipotézis vizsgálatokra (TÓTHNÉ, 2011). A Chi² próbával a nullhipotézist tudjuk vizsgálni abban a tekintetben, hogy a két választott paraméter független, vagy nem független egymástól. Ha a hozzá tartozó szignifikancia szint 5\% alatt van, akkor elvetjük a nullhipotézist. Amennyiben a két paraméter nem független egymástól, akkor a kapcsolat erősségét a Cramer-féle asszociációs együttható adja meg. Ha a végeredmény 0,5 és 1 között van akkor erős a kapcsolat, ha alatta, akkor gyengébb. Azért hogy pontosan megismerjük, mely sor és oszlopváltozónál van szignifikánsan kisebb vagy nagyobb érték az elvártnál az egyes paraméterek értékeinek maradványértékét vizsgáljuk meg (standard residual). 


\section{EREDMÉNYEK - RESUltS}

Első kérdésünkkel azt vizsgáltuk, hogy válaszadóink milyen gyakran fogyasztanak gluténmentes kenyeret. Az eredményeket az 1. ábra szemlélteti.

A kenyér, kifli, zsemle, valamint az egyéb friss sós és édes péksütemények napi táplálkozásunk részét képezik (GFK, 2011). A magyarok a kenyeret is kenyérrel eszik, mondják sokan rólunk. Az 1. ábra is alátámasztja, a kenyér alapvető szerepet tölt be a magyar étkezési kultúrában még a gluténmentes diétában is. Naponta többször (50\%) is fogyasztják a válaszadók. Ennek magyarázata kultúránkban, hagyományainkban gyökerezik és tradicionális ételeinkre, (mint a gulyás és a számtalan pörkölt féleség) vezethető vissza.
A kenyér központi szerepe, értéke megjelenik számos szólásunkban, közmondásunkban is. (Kenyeret keres. A pap is kenyérért prédikál. Egy kenyéren élnek. Kenyere ez neki. Megette a kenyere javát. Kenyértörésre kerül. Kölcsön kenyér visszajár. Olyan, mint egy falat kenyér. Madárlátta kenyér. stb.) A reggeli a legmeghatározóbb fó étkezés Magyarországon, mint ahogy egyik szólásmondásunk is utal rá: Reggelizz, mint egy király, ebédelj, mint egy polgár és vacsorázz, mint egy koldus. A hagyományos magyar reggeli kenyér, illetve péksütemény alapú. A reggelin túl, a legtöbb szülő gyermekének tízóraira, uzsonnára szendvicset készít, ami szintén kenyér, illetve péksütemény alapú. Mint ahogy azt a 2. ábra szemlélteti, a reggeli kenyér nélkül csaknem elképzelhetetlen a válaszadók körében.

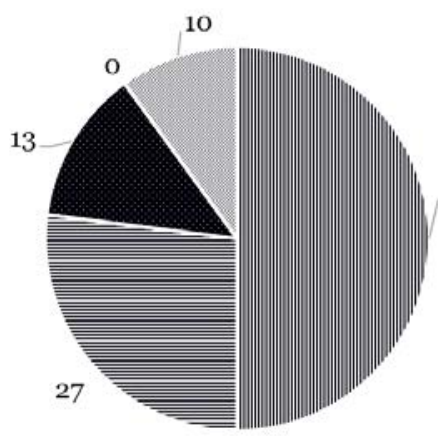

III naponta többször (several times per day)

ミnaponta egyszer (once a day)

\section{0}

- hetente kétszer-háromszor ( twothree times per week)

" hetente egyszer (once a week)

ritkábban ( less often)

\section{1. ÁBRA}

Gluténmentes kenyér fogyasztásának megoszlása (\%), N=196 (Distribution of Gluten-free Bread Consumption (\%), $\mathbf{N}=196)$

FIG. 1

Forrás (Source): Saját kutatás, 2017 (Own research, 2017)

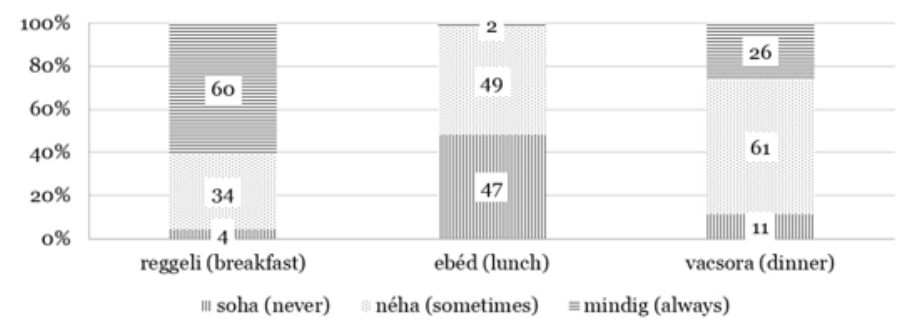

2. ÁBRA

Gluténmentes kenyérfogyasztás megoszlása fó étkezésekhez, \% (N=196)

FIG. 2 (Distribution of Gluten-free Bread Consumption to Main Meals, \% $(\mathrm{N}=196)$ )

Forrás (Source): Saját kutatás, 2017 (Own research, 2017) 
A gluténmentes kenyerek és péksütemények különböznek hagyományos társaiktól (összetevők, szín, puhaság, rugalmasság, stb.) Ezen termékek beszerezhetősége is más, nem olyan egyszerúen, könnyen vásárolhatók meg, mint a hagyományos kenyerek és péksütemények. Ha a fogyasztó hozzáférési lehetőségei korlátozottak (pl. faluban él), feltételezhetjük, hogy ritkábban vásárol gluténmentes kenyeret és péksüteményt, de akkor nagyobb mennyiségben, ami elegendő legalább egy hétre vagy még hosszabb időre. Egy másik ésszerü magyarázat a ritkább vásárlási gyakorlatra (50\% és
78\%), az, hogy a válaszadók a vásárolt kenyeret és péksüteményeket kiegészítik saját maguk által sütöttekkel. Kutatásunk feltárta, hogy a válaszadók 51,3 százaléka többnyire vásárolja a kenyeret. Ami a gluténmentes péksütemények vásárlást illeti, válaszadóink 62,8 százaléka szokott vásárolni, 32,7 százaléka pedig nem. Az 1. táblázat a gluténmentes kenyerek és péksütemények vásárlási gyakoriságát mutatja. A gluténmentes péksütemények vásárlási gyakorisága jóval alatta marad a kenyérének, válaszadónk napi szinten egyáltalán nem vásárolják, két-három naponta is csak 4 százalékuk teszi.

Gluténmentes kenyér és péksütemény vásárlások megoszlása, \% $(\mathrm{N}=196)$

(Buying Distribution of Gluten-free Bread and Baked Goods, \% (N=196))

\begin{tabular}{lcc}
\hline \multicolumn{1}{c}{ Vásárlás megoszlása (Buying distribution) } & Kenyér (Bread) & Péksütemények (Baked goods) \\
\hline naponta (daily) & 1 & 0 \\
\hline két-három naponta (every two-three days) & 25 & 4 \\
\hline hetente (weekly) & 24 & 18 \\
\hline ritkábban (less often) & 50 & 78 \\
\hline
\end{tabular}

Forrás (Source): Saját kutatás, 2017 (Own research, 2017)

A magyarok jellemzően inkább hagyományos üzletekben vásárolnak, mint kisboltokban, szupermarketekben vagy hipermarketekben. A webáruházakból való vásárlás folyamatosan emelkedő tendenciát mutat, de még közel sem olyan gyakoriságú, mint a hagyományos üzletekból való vásárlás. A 3. ábra is alátámasztja ezt a tényt, mely a gluténmentes kenyerek és péksütemények vásárlási helyszíneit szemlélteti a válaszadók körében. A speciális diétát követő emberek szaküzletekben nagy biztonsággal tudják megtalálni a számukra szükséges élelmiszereket és táplálék kiegészítőket, melyek többnyire nagyobb városokban lelhetők fel. A válaszadók az ilyen szaküzleteket részesítik előnyben. Ezeket követik a szupermarketek és a hipermarketek, mint a gluténmentes kenyér és péksütemény vásárlások leggyakoribb helyszínei. A szaküzletekben a gluténmentes kenyér és péksütemény választék jóval nagyobb és nagy valószínúséggel a személyes kapcsolat, az üzletek atmoszférája, a bizalom is fellelhető a háttérben. MOLNÁRFI
(2014) is említi írásában, hogy a szakboltokban érezhetően nagyobb bizalom lengi körül a vásárlókat. Interjúalanya elmondja, hogy az előírások köztudottan nagyon szigorúak, így ha egy gyártó nem mellékelte a laboreredményt, vagyis nem bizonyított a termék „tisztasága”, akkor több tízezer forintért külön vizsgálatra küldik. Minden vevőjüket ismerik és nagyobb távolságokról is vannak rendszeres vásárlóik. Munkatársaik zöme maga is érintett, de dietetikusokkal és élelmiszermérnökökkel is együttmúködnek. Mindezek alapján joggal állíthatják, hogy a hipermarketek nem jelenthetnek igazi konkurenciát számukra. Megnyugtató egy cöliákiás beteg számára, hogy olyan környezetben vásárolhat, kérhet tanácsot, segítséget, ahol érintettek között van, akik valóban át tudják érezni a helyzetét. A legkézenfekvőbb oka a gluténmentes kenyér és péksütemény szupermarketben vagy hipermarketekben való megvásárlására az, hogy a válaszadók együtt intézik ezen termék beszerzését a többi beszerezni kívánt termékkel. 
3. ÁBRA

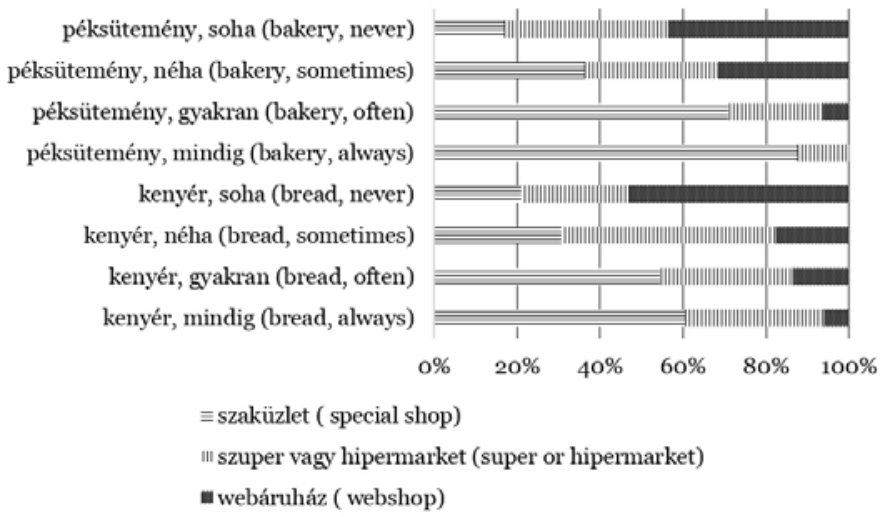

Gluténmentes kenyér és péksütemény beszerzési helyszíneinek megoszlása $(\mathrm{N}=196)$ (Distribution of the Locations of Gluten-free Bread and Baked Goods Purchases, $\mathbf{N = 1 9 6 )}$

Forrás (Source): Saját kutatás, 2017 (Own research, 2017)

Megkérdeztük válaszadóinkat, hogy lojálisak-e egy adott kenyér márkához, ugyanazt a márkát vásárolják-e folyamatosan $(\mathrm{N}=196)$. Kutatásunk feltárta, hogy óvatosak válaszadóink. 30,8 százalékuk „igen, mindig”, 39,7 százalékuk azt válaszolta, hogy „igen, többnyire”, és csak a fennmaradó 29,5 százalék válaszolt nemmel. A leggyakoribb, legkönnyebben fellelhető általunk felsorolt kenyérmárkák közül kellett a következőkben megjelölniük azt, hogy azokat milyen gyakorisággal (mindig, gyakran, néha, soha) vásárolják. A felsorolt márkák a következőek voltak: Schär, Mester Család, Nutri Free, Glutenix, Enjoy Free, Spar Free From, Glulu. A márkák kiválasztására előzetes bolti feltérképezés után került sor. Kutatásunk feltárta, hogy válaszadóink körében a Schär, Enjoy Free és Mester Család a legnépszerúbb kenyér márkák. A kapott eredményeket a 2. táblázat szemlélteti.

2. TÁBLÁZAT

TABLE 2

Gluténmentes kenyér és péksütemény vásárlások megoszlása, \% (N=196)

(Buying Distribution of Gluten-free Bread and Baked Goods, \% (N=196))

\begin{tabular}{lcc}
\hline $\begin{array}{c}\text { Milyen márkájú kenyeret szokott vásárolni? } \\
\text { (Which bread brand do you buy?) }\end{array}$ & $\begin{array}{c}\text { Mindig } \\
\text { (Always) }\end{array}$ & $\begin{array}{c}\text { Gyakran } \\
\text { (Often) }\end{array}$ \\
\hline Schär & 54,0 & 45 \\
\hline Enjoy Free (Aldi) & 28,5 & 18 \\
\hline Mester Család & 7,0 & 16 \\
\hline Glutenix & 3,5 & 7 \\
\hline Spar Free From & 3,5 & 7 \\
\hline Glulu & 3,5 & 0 \\
\hline Nutri Free & 0,0 & 7 \\
\hline
\end{tabular}

Forrás (Source): Saját kutatás, 2017 (Own research, 2017) 
Megkérdeztük válaszadóinkat, hogy elégedettek-e a magyarországi gluténmentes kenyér és péksütemény választékkal. A gluténmentes kenyér választékkal válaszadóink 14,1 százalékuk teljes mértékben elégedett, 37,2 százalékuk részben, 48,7 százaléka nem elégedett. A gulténmentes péksütemény választékkal 6,4 százalékuk teljes mértékben elégedett, 25,6 százalékuk részben, 65,4 százalékuk nem elégedett, egyéb választ a válaszadók 2,6 százaléka adott. Megkérdeztük véleményüket a Magyarországon kapható gluténmentes kenyerek és péksütemények minőségével kapcsolatosan is. A gluténmentes kenyerek minőségével a válaszadók 10,2 százalékuk teljes mértékben, 43,6 százalékuk részben van megelégedve 46,2 százaléka nincs megelégedve. A gluténmentes péksütemények minőségével a válaszadók 6,4 százaléka teljes mértékben meg van elégedve, 33,3 százaléka részben meg van elégedve, 53,8 százaléka nincs megelégedve. Egyéb választ („nem tudom megítélni”, „alig-alig”) a válaszadók 6,5 százaléka adott. A gluténmentes termékek ára magasabb, mint a hagyományos termékek ára, így vizsgáltuk azt is, hogy válaszadóink mennyire vannak megelégedve a Magyarországon kapható gluténmentes kenyerek és péksütemények árával. Összegzésképpen megállapíthatjuk, hogy válaszadóink meglehetősen magasnak tartják a gluténmentes kenyerek árát (irreálisan drága: 34,6\%; drága: 44,9\%; kissé drága: 19,2\%; reális: 1,3\%). Hasonló eredményeket kaptunk a gluténmentes péksütemények árára vonatkozóan is (irreálisan drága: 35,9\%; drága: 39,7\%; kissé drága: 16,7\%; reális: 6,4\%; egyéb válasz: $1,3 \%$ ).

$\mathrm{Az}$ eddig ismertetett eredménynek (választék, minőség, ár) magyarázatként is szolgálhatnak a következő eredményhez, miszerint válaszadóink 74,4 százaléka szokott kenyeret sütni, bár a kenyérsütés gyakorisága eltérő. Vizsgáltuk, hogy miért és milyen gyakorisággal sütnek kenyeret. A következő eredményeket kaptuk: 11,5 százalékuk csak a saját maguk által sütött kenyérben bíznak meg, 23,1 százalékuk nincs megelégedve a megvásárolható kenyerek minőségével, ugyancsak 23,1 százalékuk pedig drágának találja a kenyerek árát. A kenyérsütés gyakoriságára vonatkozó kérdésünkre a követ- kező eredményeket kaptuk: 21,8 százalékuk hetente kétszer süt, 24,4 százalékuk hetente egyszer, 25,6 százalékuk ritkábban, 2,6 százalékuk soha nem süt Ismét rákérdeztünk a márkahűségre is. Kíváncsiak voltunk rá, hogy válaszadóink lojálisak-e egy adott gluténmentes kenyérliszt keverékhez vásárlásaik során. A következő eredményeket kaptuk: 21,8 százalékuk mindig ugyanazt a márkát használja, 57,7 százalékuk többnyire márkahü, de szokott kísérletezni más márkákkal is, 17,9 százalékuk nem vallja magát márkahűnek, 2,6 százalékuk egyéb választ adott. Ezek alapján kijelenthetjük, hogy válaszadóink lojálisak a már megszokott márkáikhoz. A következő kérdéssel azt kívántuk kideríteni, hogy az általunk felsorolt gluténmentes kenyér lisztkeverékek (Anna Panni, Doves Farm, Mester Család, Amisa, Barbara, Bauck Hof, Dia-Welness, Emese, FE-MINI, Glutenix, „saját lisztkeverékem”, Nutri free, Szafi free) közül melyek a legnépszerúbbek, melyik márkát milyen gyakorisággal vásárolják. A márkák kiválasztására előzetes bolti feltérképezés után került sor. Ezen felsorolt márkák közül a Szafi free $(19,2 \%)$ bizonyult a legnépszerúbbnek, ezt követte a 10,3-10,3 százalékkal a „saját lisztkeverékem” és a Nutri free, majd 9 százalékkal harmadik legnépszerübb márkaként a Mester Család jelent meg. Amint ez már kiderült az előzőekben, gyakori válaszadóink körében a kenyérsütés. Több féle lehetőség kínálkozik kenyérsütésre, például elektromos sütő, gázsütó és kenyérsütő gép. A továbbiakban azt vizsgáltuk, hogyan/miben sütnek kenyeret. A válaszadók 47,4 százaléka elektromos sütőben, 16,7 százaléka gáz sütőben és 11,5 százaléka kenyérsütő gépben süt kenyeret. A fennmaradó válaszadók egyéb lehetőséget neveztek meg, mint például gofri sütő vagy kemence. Ahogy az már említésre került, a gluténmentes kenyerek több szempontból is különböznek a hagyományos kenyerektől. Szerettük volna kideríteni, hogy válaszadóink számára milyen is az ideális kenyér. A következő jellemzőket soroltuk fel számukra, melyek fontosságát 1-7 Likert skálán kellett jelölniük: puha, fehér, barna, magvas, cipó formájú, hosszabb ideig puha. Leggyakoribb válaszok $(\mathrm{N}=196)$ az egyes jelzőkre a 4 . ábrán láthatók. 


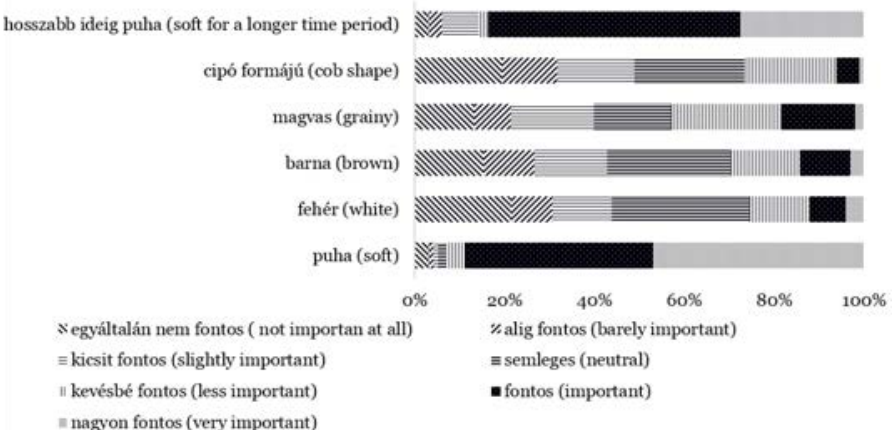

4. ÁBRA

nagyon fontos (very important)

FIG. 4

Az ideális gluténmentes kenyér (\%) ( $\mathrm{N=196)}$ (The Ideal Gluten-free Bread (\%), N=196)

Forrás (Source): Saját kutatás, 2017 (Own research, 2017)

Felmérésünkből kiderült, hogy leginkább a puhasággal és minél hosszabb ideig tartó puhasággal jellemezhető válaszadóink szerint az ideális kenyér. Egyáltalán nem szükséges, hogy fehér legyen vagy cipó formájú, a barna szín és magokkal való dúsítás pedig semleges megítélést kapott.

A bevezetésben leírt megfigyeléseink és a köznapi gondolkodás mentén megfogalmaztunk egy hipotézist mely szerint: A két paraméter hogy süt-e valaki kenyeret vagy sem és hogy hol lakik független egymástól, mert úgy gondoltuk, hogy a kenyérkészítés mindenkinek elérhető. Megfogalmaztunk egy alternatív hipotézist is: A két paraméter, hogy süt-e valaki kenyeret vagy sem és hogy hol lakik nem független egymástól. Kereszttábla elemzés (3. táblázat) segítségével vizsgáltuk a hipotézist. A Chi ${ }^{2}$ próbához tartozó szignifikancia szint $\mathrm{p}<$ o,oo1, ami azt jelenti, hogy a nullhipotézist el kellett vetnünk. Így az alternatív hipotézist tudtuk megerősíteni. A függőség erősségének vizsgálata során a Cramer-féle V együttható értéke 0,33, ami gyenge közepes függőséget jelent. A standard residual értéke 2 helyen haladja meg az abszolútérték kettő (|2|) értéket. Ezek szerint a fővárosban a nemek esetében a 28 fó lényegesen több mint az elvárt érték, illetve az egyéb városokban szignifikánsan kevesebbszer válaszoltak nemmel, mint ahogy elvárható. A kereszttábla elemzésből levonhatjuk azokat a következtetéseket, hogy minden településen legalább az érintettek 50\%-a süt kenyeret. A fóvárosban nagyjából fele-fele arányban sütik, vagy vásárolják a kenyeret, az egyéb településeken $1 / 3-2 / 3$ az arány. A legnagyobb különbség az egyéb városok- megyei jogú városoknál figyelhető meg ahol a válaszadók 80-90\%-a süt kenyeret. 
TABLE 3

Kereszttábla elemzés település típus és kenyérsütési szokások között (Cross-tab Analy sis between Type of Residence and Bread Baking Habits)

\begin{tabular}{|c|c|c|c|}
\hline \multirow{2}{*}{$\begin{array}{l}\text { Település típus } \\
\text { (Type of residence) }\end{array}$} & \multicolumn{3}{|c|}{$\begin{array}{l}\text { Szokott Ön kenyeret sütni? }(\mathrm{N}=196) \\
\quad \text { (Do you bake bread? } N=196)\end{array}$} \\
\hline & Igen (Yes) & Nem (No) & Total (Total) \\
\hline \multirow{3}{*}{$\begin{array}{l}\text { Egyéb település (other settlement type): darab (count), elvárt } \\
\text { (expected), standardizáld rezidium (std. resid) }\end{array}$} & 30 & 16 & 46 \\
\hline & 33,3 & 12,6 & \\
\hline & $-0,58$ & 0,93 & \\
\hline \multirow{3}{*}{$\begin{array}{l}\text { Egyéb város (other town): darab (count), elvárt (expected), } \\
\text { standardizáld rezidium (std. resid) }\end{array}$} & 50 & 4 & 54 \\
\hline & 39,1 & 14,8 & \\
\hline & 1,74 & $-2,82$ & \\
\hline \multirow{3}{*}{$\begin{array}{l}\text { Megyei jogú város (seat of county): darab (count), elvárt } \\
\text { (expected), } \\
\text { standardizáld rezidium (std. resid) }\end{array}$} & 26 & 6 & 32 \\
\hline & 23,0 & 8,8 & \\
\hline & 0,58 & $-0,95$ & \\
\hline \multirow{3}{*}{$\begin{array}{l}\text { Főváros (capital): darab (count), elvárt (expected), } \\
\text { standardizáld rezidium (std. resid) }\end{array}$} & 36 & 28 & 64 \\
\hline & 46,3 & 17,6 & \\
\hline & $-1,52$ & 2,47 & \\
\hline Total (Total): darab (count) & 142 & 54 & 196 \\
\hline
\end{tabular}

Forrás (Source): Saját szerkesztés GNU PSPP-vel, 2017 (Own construction with GNU PSPP, 2017)

\section{KÖVETKEZTETÉSEK ÉS JAVASLATOK - CONCLUSIONS AND SUGGESTIONS}

Primer kutatásunkkal alátámasztottuk, hogy a kenyér központi helyet foglal el a gluténmentes diétát folyatatók étrendjében is. A reggeli gyakorlatilag elképzelhetetlen kenyér nélkül még a gluténmentes diétában is. Válaszadóink 51,3 százaléka többnyire vásárolja a kenyeret és 62,8 százalékuk szokott gluténmentes péksüteményeket is vásárolni. A válaszadók 50 százaléka ritkábban, mint hetente, míg 24 százaléka heti rendszerességgel vásárol gluténmentes kenyeret. Gluténmentes péksüteményeket a válaszadók 78,2 százaléka ritkábban, mint hetente, míg 17,9 százaléka hetente vásárol. Válaszadóink a szakboltokat részesítik előnyben gluténmentes kenyér- és péksütemény vásárlásaik során. Ami a lojalitást illeti, válaszadóink 2/3-a lojális valamely gluténmentes kenyér márkájához, valamint több, mint 3/4-a lojális kenyérliszt keverékéhez. Amíg a gluténmentes kenyér választékot elfogadhatónak gondolják, addig a péksütemény választékot nem tartják elfogadhatónak a válaszadók. Az árakat mind a kenyerek, mind a péksütemények esetében magasnak vélik. A válaszadók 74,4 \%-a süt kenyeret, de a kenyérsütés gyakorisága eltérő. A nem fővárosban élő városlakók 80-90 \%-a süt kenyeret, míg a nem városi lakosok mindössze 60\%-a.

Továbbra is kihívás a gluténmentes gyártók számára a gluténmentes kenyerek és péksütemények minőségének, állagának, élvezeti értékének javitása. Gluténmentes lisztkeverékek vonatkozásában is van még lehetőség az innovációra. A gluténmentes termékek magasabb ára megterhelő a gluténmentes diétát folytatók számára. Ez annál inkább is súlyos kérdés, mert az egészségügyi okokból diétázni kényszerülők számára nem lehetséges „,más” élelmiszer választása. A márkahűség erősnek bizonyult, ami lehetőséget kínál az erős márkák számára újabb termékekkel megjelenni a gluténmentes piacon. A lisztkeverékek mellé gyártói receptek kínálása igen hasznos a fogyasztók számára (és a lisztkeverékek is jobban eladhatók ezáltal), hiszen ezek összetétele igen eltérő, így a fogyasztónak nem kell kísérleteznie, hogy az egyes lisztkeverékekből hogyan és milyen kenyeret, (pék)süteményt lehet készíteni. 


\section{5. ÖSSZEFOGLALÁs - SUMMARY}

A cöliákia egy krónikus autoimmun rendellenesség. Világszinten 100 emberből 1, Magyarországon a népesség 1-2 százaléka érintett. Az egyedüli lehetőség a betegséggel való együttélésre az élethosszig tartó szigorú gluténmentes diéta. Ez a búza, rozs, árpa, zab szigorú kiiktatását jelenti az étrendből. Hazánkban és a világ nagy részén a kenyér alapvetően glutén tartalmú gabonákból készül. A kenyér, a sós és édes péksütemények központi helyet foglalnak el a magyar étkezési kultúrában. A gluténmentes piac világszinten folyamatosan bővül. Gluténmentes élelmiszerekből, így kenyerekből, péksüteményekbool és liszt keverékekből is egyre nagyobb a kínálat. Ezek a kenyerek, péksütemények és lisztkeverékek azonban összetételükben, megjelenésükben, állagukban, élvezeti értékükben különböznek hagyományos társaiktól. Primer kutatásunkkal gluténmentes diétát folytatók gluténmentes kenyér és péksütemény vásárlási és fogyasztási szokásait mértük fel. A kérdőív válaszaiból megállapíthattuk, hogy a gluténmentes diétát folytató válaszadók reggelije szinte mindig tartalmaz kenyeret. A válaszadóink 51,3 százaléka többnyire vásárolja a kenyeret és 62,8 százalékuk szokott gluténmentes péksüteményeket is vásárolni. Vásárlásaik során a szakboltokat részesítik előnyben. Továbbá megismerhettük azt is, hogy a válaszadóink 2/3-a lojális valamely gluténmentes kenyér márkájához, valamint több, mint 3/4-a lojális kenyérliszt keverékéhez. Amíg a gluténmentes kenyér választékot elfogadhatónak gondolják, addig a péksütemény választékot nem tartják elfogadhatónak. Az árakat mind a kenyerek, mind a péksütemények esetében magasnak vélik.

\section{IRODALOMJEGYZÉK - REFERENCES}

Axelsson, E. - Ratnakumar, A. - Arendt, M. L. - Maqbool, K.: The Genomic Signature of Dog Domestication Reveals Adaptation to a Starch-Rich Diet. Nature. 2013. 495 (7441) 360-364 https://doi. org/10.1038/nature11837
Arendt, E. K. - O'Brien, C. M. - Schober, T. J. - Gallagher, E. - Gormley, T. R.: Development of Gluten-free Cereal Products. Farm Food. 2002. 12 65-72.

Gallagher, E. - Gormley, T. R. - Arendt, E. K.: Crust and Crumb Characteristics of Gluten Free Breads. Journal of Food Engineering. 2003. 56 (2-3) 153161. https://doi.org/10.1016/So2608774(02)00244-3

GfK: Friss pékáruknál a kisboltok mennyiségi részesedése 47 százalék. 2011. http:// www.piackutatasok.hu/2011/11/gfkfriss-pekaruknal-kisboltok.html (Letöltés dátuma: 2018. jan. 11.)

Jargon, J: The Gluten-Free Craze: Is It Healthy? 2014. https://www.wsj.com/ articles/how-we-eat-the-gluten-freecraze-is-it-healthy-1403491041 (Letöltés dátuma: 2017. dec. 22.)

Hanula, Zs.: Mentes=Egészséges? https:// index.hu/tudomany/2016/o6/13/ mentes_egeszseges/ (Letöltés dátuma: 2018. jan. 11.)

Klicsu, N. - Pálfi, E.: A gluténmentes diéta költségei. Új diéta. A magyar dietetikusok lapja. 2007. (6) http://www.ujdieta.hu/ index5556.html?content=699 (Letöltés dátuma: 2018. jan. 11.)

Koltai, T.: Tíz jó tanács a diétához. Gluténmentesen. A Lisztérzékenyek Érdekképviseletének Országos Egyesülete hivatalos lapja. 2016a. 20 (4) 5.

Koltai, T.: Újra felfedezett ősi gabonafélék. Gluténmentesen. A Lisztérzékenyek Érdekképviseletének Országos Egyesülete hivatalos lapja. 2016b. 20 (4) 14-15.

Koltai, T.: Gluténmentes termékek - nem csak divat. Gluténmentesen. A Lisztérzékenyek Érdekképviseletének Országos Egyesülete hivatalos lapja. 2017. 21(2) 5 .

Koltai, T.: Lisztérzékenyek Érdekképviseletének Országos Egyesülete http://www.liszterzekeny.hu (Letöltés dátuma: 2018. máj. o8.)

Lukács, A.: Nyakunkon a gluténterror: kényszer és üzlet. http://hvg.hu/ plazs/20140701_Glutenhorror (Letöltés dátuma: 2018. jan. 11.) 
Lukács, K.: Használható az áthúzott gabonakalász. Gluténmentesen. A Lisztérzékenyek Érdekképviseletének Országos Egyesülete hivatalos lapja. 2016. 20 (3) 12-15.

Molnárfi, K.: Bombaüzlet lett az ételallergia - Miért drága, ha semmi nincs benne? 2014. https://vs.hu/gazdasag/osszes/ bombauzlet-lett-az-etelallergia-miertdraga-ha-semmi-nincs-benne-1110\#!s1 (Letöltés dátuma: 2018. jan. 11.)

Amin, R. - Murphy, N. - Edge, J. Ahmed, M. L. - Acerini, C. L. Dunger, D. B.: A Longitudinal Study of the Effects of a Gluten-Free Diet on Glycemic in Subjects With Type 1 Diabetes and Celiac Disease. Diabetes Care. 2002. 25 (7) 1117-1122. https://doi.org/10.2337/ diacare.25.7.111

Thompson, T.: Folate, Iron, and Dietary Fiber Contents of the Gluten-free Diet. Journal of American Dietetic Association. 2000. 100 (11) 1389-1396 https://doi. org/10.1016/Sooo2-8223(oo)oo386-2

Tóthné Parázsó, L.: A kutatásmódszertan matematikai alapjai. Eszterházy Károly Főiskola. 2011. http://www.tankonyvtar. $\mathrm{hu} / \mathrm{hu} /$ tartalom/tamop425/ooo5_31_ kutatasmodszertan_scorm_o6/adatok. html (Letöltés dátuma: 2018. jan. 22.)
Utassy, G.: A lisztérzékeny nem kockáztathat! Glutén Mentes INFO, Információs újság gluténérzékenyeknek. 2012 (3) 9-10.

Vojnits, B.: Bármely életkorban lecsaphat a lisztérzékenység. 2012. http:// semmelweisfigyelo.hu/hu/osszes_ kiemelt_cikk/hir/306o (Letöltés dátuma: 2018. jan. 17.)

Ylimaki, G. - Hawrysh, Z. J. - Hardin, R. T. - Thomson, A. B. R.: Response Surface Methodology in the Development of Rice Flour Yeast Breads: Sensory Evaluation. Journal of Food Science. 1991. 56 (3) 751-759. https://doi. org/10.1111/j.1365-2621.1991.tbo5374.x

Yourlife: Édes mesterműveket alkotni múvészet. Yourlife Schär magazin a jobb életminőségért. 2010. 16 (11) 3-5.

Weborvos: Fókuszban a coeliakia. Gluténmentesen. A Lisztérzékenyek Érdekképviseletének Országos Egyesülete hivatalos lapja. 2016. 20 (4) 2.

Whiteman, H.: Is a Gluten-Free Diet Good for Your Health? https://www. medicalnewstoday.com/articles/288406. php (Letöltés dátuma: 2018. febr. 19.)

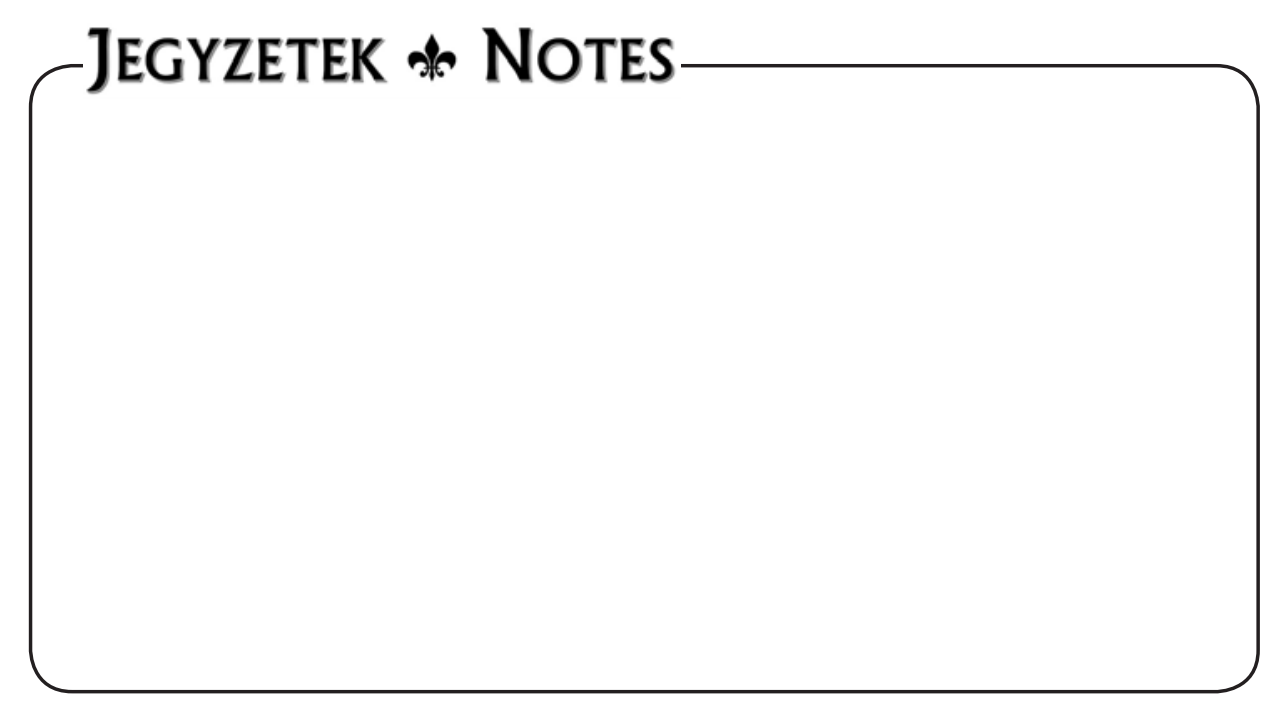

